\title{
The Cyprus Peace Talks at Mont Pelerin (7-11 and 20-21 November 2016) and the Greek Cypriot Press: The Positions of Cypriot Newspapers Alithia, Politis and Haravgi
}

\author{
Dr. Euripides Antoniades \\ Faculty of Communication and Mass Media, Department of Communication \& Internet Studies, \\ Cyprus University of Technology,
}

Abstract

This text is based on research aiming to record the period of negotiations at Mont Pèlerin, Switzerland between the Greek Cypriot and Turkish Cypriot community in November 2016. Articles from three newspapers (Alithia, Politis and Haravgi) were studied, with an emphasis on political coverage regarding the negotiations. The choice of newspapers was based on the fact that they have been around for many decades, they have a different ideological orientation and they have contributed to the modern history of Cyprus. Moreover, they all have a full electronic archive of their issues which makes it easy to access and study the articles. The overarching aim is to understand the efforts to solve the Cyprus problem through the recent negotiations in Switzerland and to examine the positions of the Cypriot press regarding this thorny and crucial issue over which the Republic of Cyprus has been agonising for more than forty years.

Keywords: The Cyprus Peace Talks at Mont Pelerin (7-11 and 20-21 November 2016) and the Greek Cypriot Press: The Positions of Cypriot Newspapers Alithia, Politis and Haravgi

\section{Introduction}

The Cyprus issue emerged, in practical terms, on the day of declaration of independence of the Republic of Cyprus, on 16 August 1960, following the armed struggle of the National Organisation of Cypriot Fighters (EOKA) between the years 1955-1959 and a summit in London on 19 February 1959, attended by representatives from Greece, Turkey, the UK and the two Cypriot communities. Over the course of time, it was made clear that the implementation of certain provisions of the newly-signed Constitution presented serious problems and, as a result, the Turkish Cypriot ministers and members of the Parliament withdrew from the Cabinet and the House of Representatives respectively and formed separate bodies of executive and legislative power for their community. On imposition of the military dictatorship in Greece in 1967, things got even more complicated. After the establishment of the dictatorship of 21 April 1967 in Athens, the relations between Greece and Cyprus deteriorated gradually. On 15 July 1974, military coup was launched in Cyprus, organised by the Junta aiming at the deposition of president Makarios. Makarios managed to escape to Paphos initially and then to Akrotiri British Sovereign Base, before travelling abroad. Five days later, Turkey, using a long-sought pretext, invaded the island on 20 July 1974 and, to this date, holds $37 \%$ of the territory of Cyprus.

Since 1977, several rounds of talks were held between the two sides for an overall settlement of the problem with the then Secretary General of the United Nations, Kurt Waldheim to the current Secretary General, Antonio Guterres, without success. The most recent talks took place at Crans Montana, Switzerland in July 2017 and reached a dead-end.

In 2016, the Cyprus problem reached a crucial point in the history of efforts in search of a solution, with the meeting between the president of the Republic of Cyprus Nicos Anastasiades and the Turkish Cypriot leader Mustafa Akinci at Mont Pèlerin, Switzerland. Following two rounds of talks, Anastasiades and Akinci were unable to achieve the necessary convergence on the criteria for territorial adjustments that would pave the way for the last act of the talks. According to the Special Adviser of the Secretary-General on Cyprus, the two sides decided "to return to Cyprus and examine the way forward" (Politis, 21 November 2017).

This paper aims to record and analyse press publications during the UN-led talks on the reunification of Cyprus in November 2016 at Mont Pèlerin, Switzerland between the Greek Cypriot and Turkish Cypriot communities. Articles from three Greek Cypriot newspapers (Alithia, Politis and Haravgi) were studied, with an emphasis on political coverage regarding the peace 
talks. The choice of newspapers was based on the fact that they have been in circulation for many decades ${ }^{1}$, they have a different ideological orientation ${ }^{2}$ and they have contributed to the modern history of Cyprus. Moreover, they all have a full electronic archive of their issues which made it easy to access and study the articles.

The overarching aim is to understand the efforts to seal a deal to reunify Cyprus through the recent negotiations in Switzerland and to review the positions of the Cypriot press regarding this thorny and crucial issue over which the Republic of Cyprus has been agonising for more than forty years.

\section{The study}

As is the case with media across the world, the Cypriot media undertake the task of keeping the public informed and up-to-date. They play the role of the Fourth Estate since people rely on media for the exercise of criticism on the Executive Estate (Sofokleous, 2008:167). Newspapers, as a traditional form of the Press, are always a notable and reliable medium as they cover several topics with the aim of informing the public. The Cypriot Press has existed for 130 years and judging by the circumstances on the island all these years with the on-going occupation by the English and the Turks, its presence and development has been particularly difficult (Sofokleous, 1995). For the record, the first Cypriot newspaper was printed in 1878 in Larnaca by Theodoulos Constantinides. During World War II, the Cypriot Press started to gradually gain freedom and independence. Its contribution to the national liberation struggle of 1955-1959 was considerable. Several Greek Cypriot journalists were persecuted, tortured and imprisoned in concentration camps, mostly because they wrote articles against the establishment of that period (Sofokleous, 2006). Today, five daily and ten weekly newspapers are available in Greek for Cypriot readers.

As already mentioned the object of our study is to record and present the peace talks as covered by the Greek Cypriot Press during the period starting from 1 November 2016 and ending on 30 November 2016. More particularly, we focus on political articles in newspapers Alithia, Politis and Haravgi and on how they reported the negotiations between the two communities.

Alithia newspaper was founded in 1952 by the late Antonis Farmakides as a weekly newspaper. Antonis Farmakides is considered one of the pioneers of Cypriot journalism. Weekly Alithia, following its Monday issue on 15 July 1974, was forced to suspend its circulation for a few weeks due to the circumstances that occurred as a result of the military coup and the subsequent Turkish invasion. It re-circulated on 5 August 1974 with a detailed report on the tragedy that hit Cyprus and an optimistic message. Today, Alithia has completed 35 years of presence as a daily newspaper

Politis newspaper was first issued on 12 February 1999. The newspaper has made a firm commitment to provide all-round and impartial information and to adhere to the principles of independence, impartiality, truth, freedom of speech and pluralism. It is not a newspaper of extreme ideology. It has demonstrated responsibility and, naturally, it endeavours to feature the sensitivities and interests of small and bigger groups of Cypriot society and to bring Cyprus even closer to European affairs, thus broadening the horizons of knowledge and experience.

Haravgi has large, island-wide circulation and is the medium of expression of left-wing party AKEL (Progressive Party of the Working People). Its first issue was published in Nicosia on 18 February 1956. In a main article titled "Setting off" on the front page of its first issue, the newspaper states "[...] our newspaper will strive to offer high-quality material to our readers. Aside from news reporting that will be our top priority, there are several other topics worthy of attention." (Sofokleous, 2011:394)

\section{Methodology and Objectives}

Our methodology was based on elements of content quality analysis which we thought was most appropriate, since "the great strength of content analysis is that it analyses the whole message system, and not the individual's selective experience of it" (Fiske 2010:139). This method is suitable when cultural issues are examined since it "takes account of notion systems deriving from culture" (McQuail 2003: 382) and assists in analysing the features of the text message, discourse and form (Constantinidou, 1998) and involves five stages (ibid, 1998):

The procedure of compiling the empirical evidence

The isolation of items (units recorded)

The classification of units recorded into categories 
The quantity conversion and measurement of items (codification)

Analysis and interpretation of data.

More specifically, the research involved the recording of daily news items in daily newspapers of island-wide circulation and the identification of the main political news stories in the above newspapers. In this case, the role of the Press is paramount in ensuring that there exist conditions that enable citizens to stay well informed and up-to-date. We recorded the articles and we then classified them into six categories as follows: a) Republic of Cyprus, b) Greek Cypriot community, c) Turkish Cypriot community, d) countries involved (i.e. the guarantor countries in accordance with the Treaty of Establishment of the Republic of Cyprus, namely Greece, Turkey and the UK), e) United Nations and f) European Union.

During the first stage, we identified the empirical evidence, namely the news stories that were relevant to our research. During the second stage, we isolated the stories that could be incorporated. The third stage involved the codification, i.e. the classification of topics into categories. During the fourth stage, we converted the quantitative items into such form so that they could be processed on the computer, compared and analysed (ibid, 1998). During the fifth stage, the data was presented, analysed and interpreted. A thematic analysis helps to answer questions such as how the negotiations between the two communities are presented, why it is possible to record views and conceptions through political news items published in the political columns and subsequently make a connection of all this. Moreover, by putting the news items into categories, we can identify the different positions/ opinions expressed and have them in one place.

The one-month period that was examined was chosen primarily on the basis of the working hypotheses, as well as the material under study. The events taking place in November 2016 were of particular significance and the daily issues of newspapers covered a range of stories and topics and made extensive reviews on the progress made during the week. The extent of the duration is just right to support our hypothesis, as it allows us to shape an opinion on the varied reflections expressed by the Greek Cypriot community, which take form and change as the events unfold on both a local and international level.

From the newspaper issues, we focused on the political and news sections which include a plethora of news reports, articles and reportages. Moreover, the political section is dominated by highly interesting, catchy headlines that attract readers and draw them into buying a newspaper. Choosing the material is a difficult task, since as many titles as possible need to be selected from a vast pool of items.

More particularly, the working hypotheses are the following:

If the newspaper's positions have a conflictual or reconciliating tone;

Whether the tone of the news items regarding the talks varied depending on the newspaper;

Whether the articles were signed or unsigned; if unsigned, this probably means that journalists, as individuals, were reluctant to be associated with the talks.

Our research relates to the period of November 2016. Overall, 281 news items were scrutinised as units of analysis from the three newspapers (Alithia 108, Politis 104, Haravgi 69). In order to examine items on the front page, the following pattern of typical categories/ variables was used:

Political news stories that were relevant to the subject were classified based on their type as follows: Main Article, Opinion Article - Analysis - Comment/ Commentary, Reportage, Interview, Announcement, Letter, Simple Report, Other

In order to investigate the content of news, the number of references in each article was recorded so as to create a list of protagonists: President Anastasiades, Mustafa Akinci, Espen Barth Eide, Alexis Tsipras, Nikos Kotzias, Recep Tayyip Erdoğan etc.

The news items were recorded on the basis of source, origin of source and editor of the article (signed, unsigned, international news agency, special report).

If the newspaper positions were in favour or against the positive progress of the peace talks and the prospect of a deal.

\section{RESULTS OF THE RESEARCH}


TABLE 1: References in newspapers Alithia, Politis and Haravgi

Period: 1-30 November 2016

\begin{tabular}{|c|c|c|c|c|c|}
\hline References & $\begin{array}{l}1-30 \text { November } \\
2016\end{array}$ & $\%$ & Alithia & Politis & Haravgi \\
\hline Republic of Cyprus & 222 & 22 & $84(23 \%)$ & $82(21 \%)$ & $56(21 \%)$ \\
\hline Greek Cypriot Community & 193 & 19 & $74(20 \%)$ & $73(18 \%)$ & $17 \%)$ \\
\hline Turkish Cypriot Community & 149 & 14 & $53(15 \%)$ & $63(16 \%)$ & $33(12 \%)$ \\
\hline Countries involved & 295 & 28 & $96(26 \%)$ & $110(28 \%)$ & $89(32 \%)$ \\
\hline United Nations & 123 & 12 & $40(11 \%)$ & $49(12 \%)$ & $34(12 \%)$ \\
\hline European Union & 55 & 5 & $17(5 \%)$ & $21(5 \%)$ & $17(6 \%)$ \\
\hline Total & 1037 & 100 & 364 & 398 & 275 \\
\hline
\end{tabular}

Note: Based on columns "Politics" and "News"

TABLE 2: A quantitative analysis of news items in Alithia, Politis and Haravgi

Period: 1-30 November 2016

\begin{tabular}{|c|c|c|c|c|c|c|}
\hline Article Editor & Alithia & $\%$ & Politis & $\%$ & Haravgi & $\%$ \\
\hline Signed & 21 & 19 & 64 & 62 & 21 & 30 \\
\hline Unsigned & 87 & 81 & 39 & 37 & 48 & 70 \\
\hline $\begin{array}{l}\text { International News } \\
\text { Agency }\end{array}$ & -- & & 1 & 1 & -- & \\
\hline Special Report & -- & & -- & & -- & \\
\hline Total & 108 & 100 & 104 & 100 & 69 & 100 \\
\hline \multicolumn{7}{|l|}{ Type of article } \\
\hline Main article & 44 & 41 & 47 & 45 & 27 & 39 \\
\hline Opinion article & 2 & 2 & 2 & 2 & 1 & 1 \\
\hline Reportage & 26 & 24 & 29 & 28 & 7 & 11 \\
\hline Interview & 2 & 2 & 4 & 4 & -- & \\
\hline Announcement & -- & & - & & -- & \\
\hline Letter & -- & & -- & & -- & \\
\hline Simple report & 34 & 31 & 22 & 21 & 34 & 49 \\
\hline Other & & & -- & & -- & \\
\hline Total & 108 & 100 & 104 & 100 & 69 & 100 \\
\hline \multicolumn{7}{|l|}{ Origin of source } \\
\hline Anonymous & 80 & 73 & 37 & 37 & 48 & 70 \\
\hline Greece & -- & & -- & & -- & \\
\hline Cyprus & 29 & 26 & & & 21 & 30 \\
\hline UK & -- & & -- & & -- & \\
\hline Turkey & -- & & & & -- & \\
\hline $\begin{array}{l}\text { Mont Pèlerin, } \\
\text { Switzerland }\end{array}$ & -- & & 62 & 62 & - & \\
\hline $\begin{array}{l}\text { International news } \\
\text { agencies }\end{array}$ & 1 & 1 & 1 & 1 & -- & \\
\hline Other & & & & & -- & \\
\hline Total & 110 & 100 & 100 & 100 & 69 & 100 \\
\hline \multicolumn{7}{|l|}{ Focus on protagonists } \\
\hline $\begin{array}{l}\text { Nicos Anastasiades } \\
\text { (President of the } \\
\text { Republic of Cyprus) }\end{array}$ & 70 & 33 & 69 & 26 & 37 & 21 \\
\hline
\end{tabular}




\begin{tabular}{|c|c|c|c|c|c|c|}
\hline $\begin{array}{l}\text { loannis Kasoulides } \\
\text { (Foreign Minister, } \\
\text { Republic of Cyprus) }\end{array}$ & 5 & 2 & 4 & 2 & 5 & 3 \\
\hline $\begin{array}{l}\text { Nikos Christodoulides } \\
\text { (Government } \\
\text { spokesman) }\end{array}$ & 15 & 7 & 9 & 3 & 8 & 4 \\
\hline $\begin{array}{l}\text { Andreas Mavrogiannis } \\
\text { (GC negotiator) }\end{array}$ & 3 & 1 & 4 & 2 & 4 & 2 \\
\hline Archbishop of Cyprus & 2 & 1 & 1 & 1 & 1 & 1 \\
\hline $\begin{array}{l}\text { GC Party } \\
\text { Representatives }\end{array}$ & 18 & 8 & 28 & 10 & 16 & 9 \\
\hline $\begin{array}{l}\text { Mustafa Akinci (Turkish } \\
\text { Cypriot Leader) }\end{array}$ & 45 & 21 & 61 & 22 & 29 & 17 \\
\hline $\begin{array}{l}\text { Ozsdil Nami (TC } \\
\text { negotiator) }\end{array}$ & 3 & 1 & 2 & 1 & 3 & 2 \\
\hline Espen Barth Eide & 16 & 7 & 22 & 7 & 16 & 9 \\
\hline $\begin{array}{l}\text { Alexis Tsipras (Prime } \\
\text { Minister, Hellenic } \\
\text { Republic) }\end{array}$ & 14 & 7 & 26 & 10 & 17 & 10 \\
\hline $\begin{array}{l}\text { Nikos Kotzias } \\
\text { (Foreign Minsiter, } \\
\text { Hellenic Republic) }\end{array}$ & 8 & 4 & 16 & 6 & 7 & 4 \\
\hline $\begin{array}{l}\text { Prokopis Pavlopoulos } \\
\text { (President, Hellenic } \\
\text { Republic) }\end{array}$ & 3 & 1 & 2 & 1 & 3 & 2 \\
\hline $\begin{array}{l}\text { Recep Tayyip Erdoğan } \\
\text { (President, Republic of } \\
\text { Turkey) }\end{array}$ & 9 & 4 & 15 & 6 & 15 & 9 \\
\hline $\begin{array}{l}\text { Mevlüt Çavuşoğlu } \\
\text { (Foreign Minister, } \\
\text { Republic of Turkey) }\end{array}$ & 5 & 2 & 5 & 2 & 9 & 5 \\
\hline $\begin{array}{l}\text { Sergey Lavrov } \\
\text { (Foreign Minister, } \\
\text { Russia) }\end{array}$ & 3 & 1 & 1 & 1 & 4 & 2 \\
\hline Total & 214 & 214 & 265 & 100 & 174 & 100 \\
\hline
\end{tabular}

\section{The position of Alithia newspaper}

This newspaper deals with a broad range of subjects and includes "articles, news reportages on local or international events, commentaries, culture coverage, courts news, reports from the countryside and a variety of other pieces of information" (Sofokleous 2011). The research revealed that regarding the type of news item, $41 \%$ are main articles, $31 \%$ are simple news reports and $24 \%$ are reportages. 3 confirmed). The main protagonists are the following: President of the Republic of Cyprus and leader of the Greek Cypriot Community Nicos Anastasiades with 33\%, the leader of the Turkish Cypriot Community Mustafa Akinci with 21\%, representatives of Greek Cypriot parties with 8\%, the Greek Prime Minster Alexis Tsipras with 7\% and the Turkish Prime Minister Recep Tayyip Erdoğan with 4\%.

Over the period under study, Alithia maintained its government-affiliated stance, since it supports the Democratic Rally, which is President Anastasiades's political party. Alithia's objective to support President Anastasiades's efforts to solve the Cyprus problem has remained unchanged. The titles below indicate the newspaper's support towards President Anastasiades and his negotiating team:

"President Anastasiades: The solution to the Cyprus problem will be the greatest financial reform for the decades to come" (Alithia, 2 November 2016)

"First day with smiles" (Alithia, 8 November 2016) 
"Good spirit and progress during the first talks (Alithia, 8 November 2016)

"What matters most with the territorial trade-offs" (Alithia, 9 November 2016)

The subjects that appear repetitively and consistently in Alithia newspaper during the period under study are the following:

(1) The positive support of the efforts to solve the Cyprus problem:

Extracts from the newspaper:

"A solution is possible" (Alithia, 8 November 2016)

"The negotiation between Anastasiades-Akkinci about the territorial matter is fruitful" (Alithia, 11 November 2016),

"Everyone is working for the solution" (Alithia, 12 November 2016)

"Steps towards a solution" (Alithia, 12 November 2016)

(2) The spirit of reconciliation between the two communities.

Extracts from the newspaper:

"Good spirit and progress during the first talks" (Alithia, 8 November 2016)

"The climate for peace is rising" (Alithia, 19 November 2016)

"Collaboration will conquer fears" (Alithia, 20 November 2016),

(3) Reference to more important topics, such as the territorial adjustments, the property trade-offs and economic progress.

Extracts from the newspaper:

"Good spirit and progress in the discussion of pending issues of the four chapters" (Alithia, 8 November 2016)

"And now the territory issue" (Alithia, 9 November 2016),

"Progress with the four chapters still open" (Alithia, 9 November 2016),

"New meeting focusing on the territory issue scheduled for the two leaders" (Alithia, 12 November 2016),

"Property issue: The estimates regarding the compensations" (Alithia, 21 November 2016),

(4) The trend towards agreement on the European Union chapter, and more particularly the economic aspect of this chapter.

Extracts from the newspaper:

"The economic aspect of the solution before Eurogroup" (Alithia, 7 November 2016),

"The economics of the solution - Experts from the International Monetary Fund in Cyprus today" (Alithia, 9 November 2016),

(5) The British stance: the United Kingdom does not wish to remain a guarantor power and, upon solution, will return half the territory of the Sovereign Base Areas.

Extracts from the newspaper:

The High Commissioner of the United Kingdom to Cyprus, Matthew Kidd, reaffirmed the position of the British government that "in case of a deal, at least $48 \%$ of the territory of the two British Bases will be returned" which amounts to approximately $1.5 \%$ of the total territory of the Republic of Cyprus (Alithia, 9 November 2016)

"The British High Commissioner has clarified that 'the United Kingdom does not wish to remain a guarantor power"'.(Alithia, 9 November 2016)

(6) The summit on Cyprus and all the statements about Cyprus by foreign leaders about the island, as well as the 
statements by Greeks and Turks.

Extracts from the newspaper:

"The Greek government supports these talks, backs-up the overall efforts and aspires to a viable and fair solution on the basis of the resolutions of the Security Council of the United Nations" (Alithia, 9 November 2016)

"We want the issue of territory, properties, guarantees and security to be discussed last" stated the Turkish Foreign Minister (Alithia, 10 November 2016)

The Turkish Minister further stated that "Turkey supports the negotiations procedure on the Cyprus problem and expressed the hope that the Greek Cypriot side is equally honest (Alithia, 10 November 2016)

\section{The position of Politis newspaper}

As shown in Table 2, Politis has the most articles regarding the peace talks in all categories compared to the three newspapers we used in the sample. The topics that appear repetitively and consistently during the period under study in Politis newspaper are the following:

(1) The desire for a solution to the problem.

Extracts from the newspaper:

"On our way for a solution with self-confidence" (Politis, 5 November 2016)

"Time for responsibility for the two leaders" (Politis, 6 November 2016)

"The talks will determine the prospect of a solution within 2016" (Politis, 7 November 2016)

"Seeking for convergence on everything" (Politis, 8 November 2016)

"The future lies in the hands of the two leaders today" (Politis, 11 November 2016)

"The die is cast: Anastasiades - Akinci were close to an agreement at Mont Pèlerin (Politis, 13 November 2016)

"On the eve of a solution" (Politis, 20 November 2016)

(2) References to paramount issues such as territory, security and guarantees.

Extract from the newspaper:

"The Turkish Cypriot side has not come prepared to hand over a map on territory" (Politis, 10 November 2016)

(3) The European Union stance.

Extract from the newspaper:

"If Anastasiades and Akinci succeed in reaching an agreement, the EU will soon be called upon to accept a federal state with all its problems and outstanding issues" (Politis, 7 November 2016),

(4) Optimism about the future of the island.

Extracts from the newspaper:

"The future lies in the hands of the two leaders today" (Politis, 11 November 2016)

"Counting on the determination of the two leaders, the United Nations expressed the hope that a settlement will be reached" (Politis, 11 November 2016).

As expected, Politis places an emphasis on the two sides as well the guarantor countries United Kingdom, Greece and Turkey. In the period under study, $18 \%$ of the articles refer to the Greek Cypriot community, $16 \%$ to the Turkish Cypriot community, $21 \%$ to the Republic of Cyprus as represented by its President, $12 \%$ to the United Nations and $5 \%$ to the European Union. 
In $62 \%$ of the news items, Mont Pèlerin is the origin of the source, since it is the place where the talks took place and the reporter was present in Switzerland. A percentage of $37 \%$ of the items is from anonymous sources, i.e. the source is not specified.

There are no surprises regarding the people getting the most attention: President of the Republic of Cyprus and leader of the Greek Cypriot Community Nicos Anastasiades with 26\%, the leader of the Turkish Cypriot Community Mustafa Akinci with 22\%, the Greek Prime Minster Alexis Tsipras with 10\%, representatives of Greek Cypriot parties with 10\%, and the Turkish Prime Minister Recep Tayyip Erdoğan with 6\%.

With regard to the type of news item, $45 \%$ are main articles, $28 \%$ are reportages and $21 \%$ are simple news reports.

[n] of the articles are signed and $37 \%$ are unsigned.

\section{The position of Haravgi newspaper}

The topics that appear repetitively and consistently during the period under study in

Haravgi Politis newspaper are the following:

(1) During the talks on the Cyprus problem, Haravgi newspaper focuses on Switzerland and the negotiations; it is a time when the leaders of the two communities must assume historical responsibility.

Extract from the newspaper:

"We can overcome the problems and find solutions to all the open chapters of internal governance. The way to the next and possibly final step towards the solution, i.e. the international summit on the issue of security and guarantees, may be paved. If we don't succeed now, Greek Cypriots will not be the only ones burdened with a loss and a failure, but also Turkish Cypriots who will be faced with annexation and assimilation with Turkey. Wishful thinking is not enough. Greek Cypriots and Turkish Cypriots together must truly feel that now is the time to unite our country" (Haravgi, 7 November 2016).

(2) The desire for a solution.

Extracts from the newspaper:

"A time of truth for a solution to the Cyprus problem" (Haravgi, 6 November 2016)

"Optimism aiming for convergence" (Haravgi, 12 November 2016)

"The flame of hope for a solution still burns" (Haravgi, 13 November 2016)

"Obama: The Cyprus problem may be solved within the next few months" (Haravgi,16 November 2016)

"The desire for the solution is still alive" (Haravgi, 27 November 2016)

(3) The criteria of the solution.

Extract from the newspaper:

"The criteria are being discussed on the basis of a joint document" (Haravgi, 10 November 2016)

The main protagonists, as referred to in the sample under study, are the following: President of the Republic of Cyprus and leader of the Greek Cypriot Community Nicos Anastasiades with 21\%, the leader of the Turkish Cypriot Community Mustafa Akinci with 17\%, the Greek Prime Minster Alexis Tsipras with 10\%, representatives of Greek Cypriot parties with $9 \%$ and the Turkish Prime Minister Recep Tayyip Erdoğan with 9\%.

With regard to the type of news item, $49 \%$ are simple news reports, $39 \%$ are main articles and $11 \%$ are reportages. It is important to note that anonymous sources reach $70 \%$ and an equal percentage accounts for unsigned articles.

Lastly, daily articles of Haravgi newspaper in November 2016 make reference to the countries dealing with the future of the island, i.e. the Greek Cypriot community with $32 \%$, the Turkish Cypriot community with $12 \%$, the Republic of Cyprus as represented by its President with 21\%, the United Nations with 12\% and the European Union with 6\% (Table 2).

\section{Analysis and results of variables}




\section{TABLE 3}

List of framings in Alithia, Politis and Haravgi newspapers during the period of 1-30 November 2016 and whether they have a conflictual or reconciliating tone:

\begin{tabular}{|l|l|l|l|l|l|l|}
\hline Tone & Alithia & $\%$ & Politis & $\%$ & Haravgi & $\%$ \\
\hline Conflictual & 7 & $6 \%$ & 7 & $7 \%$ & 10 & $14 \%$ \\
\hline Reconciliating & 101 & $94 \%$ & 97 & $93 \%$ & 59 & $86 \%$ \\
\hline Total & 108 & 100 & 104 & 100 & 69 & 100 \\
\hline
\end{tabular}

A remarkable finding of our research is that all three newspapers use a reconciliating tone in the majority of their articles and express the wish of the two communities and guarantor countries to solve the Cyprus problem.

Newspaper Alithia writes:

"First day with smiles" (Alithia, 8 November 2016)

"The Greek government supports the talks" (Alithia, 9 November 2016)

"Constructive negotiation regarding the territorial matter between Anastasiades - Akkinci" (Alithia, 11 November 2016)

"Turkey supports the negotiations" (Alithia, 16 November 2016)

"Greek parties support the efforts towards solution" (Alithia, 18 November 2016)

Newspaper Politis writes:

"Time for responsibility for the two leaders" (Politis, 6 November 2016)

"Obama and Tsipras see a historic opportunity for a solution for Cyprus" (Politis, 16 November 2016)

"Erdogan feels that this is a historic opportunity for a solution" (Politis, 16 November 2016)

"The mother countries took over" (Politis, 21 November 2016)

Newspaper Haravgi writes:

"No army in united Cyprus" (Haravgi, 1 November 2016)

"We should apprehend each other's concerns" (Haravgi, 3 November 2016)

"Second round of great expectations" (Haravgi, 20 November 2016)

"We are ready for a solution' states Özgürgün” (Haravgi, 22 November 2016)

\section{Conclusion-discussion}

In conclusion, through daily news reporting, it becomes clear that the desire for a solution to the Cyprus problem dominates journalism. The procedure of direct talks with the mediation of the United Nations aims to resolve the dispute between the Greek Cypriot and Turkish Cypriot communities and, ultimately, to reach an agreement; the press contributes towards this by publishing relevant articles regarding this long-term objective. The reconciliation between the two communities predisposes the termination of any type of conflict between the two sides.

A comparison among the three newspapers demonstrates that all of them have faith that the Cyprus issue can be resolved through the talks. The Greek Cypriot side went to Mont Pèlerin aiming for success in the matters of territory and property. Both sides showed their cards, whilst the regulatory role of the countries involved was evident. The Greek side holds in its hands the main political demand of Turkish Cypriots, that of political equality, which is envisioned to be obtained through the acceptance of a rotating presidency. The Turkish side also wishes to discuss the issue of security guarantees.

It is worth to note that there is no name-calling, no prejudice, nothing that accuses any of the two sides for the failure of the talks at Mont Pèlerin; just sheer disappointment about the dead end of the peace talks. Alithia reports "Dead end for the territorial criteria to be continued in Cyprus" (Alithia, 22 November 2016), while Politis reports "Instead of reaching an agreement, we reached a crisis" (Politis, 22 November 2016). In the same spirit, Haravgi reports "Return from Switzerland without results" (Haravgi, 22 November 2016). Almost all newspapers provided the same coverage and this probably means that they perceived the events of the two summits in the same manner.

Another aspect that was looked into was the reporting style used in the news items of all three newspapers. For example, at Mont Pèlerin 1, there was an impression that the conditions have matured and a settlement could be achieved. Journalists' texts are written in a rather striking tone as they give the impression that an optimistic mood dominates the talks: "First day with smiles" (Alithia, 8 November 2016), "A setting of culmination with an open agenda" (Politis, 8 November 2016), "Good spirit and progress in the discussion of pending issues on the four chapters" (Alithia, 8 November 2016). At the same time, a series of logical arguments are deployed that "convince" the readers of these newspapers that a compromise between the two communities is the only feasible and viable solution sought by the two communities. 
A similar image was observed with two of the three guarantor powers, namely Greece and Turkey, as the newspapers reported on the significant role that these countries have during the talks: "Greek prime minister Alexis Tsipras clarified that Greece will have an opinion and the right to manage only in relation to the matter of guarantees" (Alithia, 23 November 2016), whilst Turkish Prime Minister Mevlüt Çavuşoğlu stated that "according to the objective for 2016, these negotiations should be fruitful and bring a result; steps should be taken for a permanent solution and a specific road map must be created that will involve the multilateral conference" (Haravgi, 26 November 2016).

Finally, the three newspapers promote a culture of consent between the two sides and, at the same time, support the direct talks between the two leaders of the two communities, a long-held position of the Republic of Cyprus.

\section{Notes}

Papathanasopoulos, "Mediterranean/Polarized Pluralist Media Model Countries," 219-28.

Stubbs and Taseli, "Newspapers, Nationalism and Empire," 286.

Ibid., 287-8.

Ibid., 286.

Krippendorff, Content Analysis.

lyengar and Kinder, News That Matters, 59-70.

Constantinidou, "Allocation of Labour According to Sex."

Ibid, 29.

Stubbs and Taseli, "Newspapers, Nationalism and Empire," 284-301.

Sofokleous, History of the Cypriot Press, Vol. E, 355.

Sofokleous, History of the Cypriot Press, Vol. E, 394.

Sofokleous, History of the Cypriot Press, Vol. C, 131.

\section{BIBIOGRAPHY}

[1] Constantinidou, Chr. "Representing the Allocation of Labour According to Sex in the Daily Athens Mass Press." PhD diss. (in Greek), Panteion University, 1998.

[2] Fiske J., Introduction to Communication Studies, translation by Messini B. - Lountzi E. (in Greek), Aigokeros, 2010.

[3] lyengar, S., and D. Kinder. News That Matters: Television and American Opinion. Chicago: University of Chicago Press, 1987.

[4] Krippendorff, K. Content Analysis; an Introduction to Its Methodology. Beverly Hills: Sage, 1980.

[5] McQuail D., Mass Communication Theory for the $21^{\text {st }}$ century, translation by Katia Metaxa (in Greek), Kastaniotis, Athens 2003.

[6] Papathanasopoulos, S. "The Mediterranean/Polarized Pluralist Media Model Countries, Introduction." In European Journalism Education, edited by G. Terzis, 219-228. Bristol: Intellect, 2009.

[7] Sofokleous, A. Contribution to the History of the Cypriot Press, Vol. A, 1878-1890, Part D (in Greek). Nicosia: Nicocles, 2006.

[8] Sofokleous, A. Contribution to the History of the Cypriot Press, Vol. C, 1900-1914, Part A (in Greek). Nicosia: Intercollege Press, 2003.

[9] Sofokleous, A. The Cypriot Mass Media (in Greek). Nicosia: Nicocles 2008

[10] Sofokleous, A. Contribution to the History of the Cypriot Press, Vol. E, 1945-1960, Part A (in Greek). Nicosia: Intercollege Press, 2011.

[11] Stubbs, J., and B. Taseli. "Newspapers, Nationalism and Empire." Media History 20, no. 3 (2014): 284-301.

\section{ELECTRONIC SOURCES}

${ }^{1}$ Alithia since 1952 and Haravgi since 1956 (Sofokleous, 2011).

${ }^{2}$ Alithia: 35 years as a daily newspaper ( 1 May 2017)

${ }^{3}$ Haravgi belongs to biased press and is "AKEL's official medium of expression" (Prodromou, 210, 343-344). 